https://jurnal.unigal.ac.id/index.php/jall/index

JALL (Journal of Applied Linguistics and Literacy), ISSN 2598-8530, February, Vol. 4 No. 1, 2020

\begin{tabular}{|ccc|}
\hline Received & Accepted & Published \\
\hline August 2020 & September 2020 & September 2020 \\
\hline
\end{tabular}

\title{
RECIPROCAL TEACHING OF READING TO PROMOTE STUDENTS' CRITICAL THINKING
}

\author{
Fitri Lestari sriwahyuni \\ fitrilestarisriwahyuni@gmail.com \\ English Education Program FKIP Galuh University \\ R. Bunga Febriani \\ bunga.febriani@gmail.com \\ English Education Program FKIP Galuh University \\ Luthfiyatun Thoyyibah \\ luthfiyatun20@gmail.com \\ English Education Program FKIP Galuh University
}

\begin{abstract}
This paper is a case study that aims at finding out the Reciprocal Teaching of Reading to Promote Students' Critical Thinking. The researchers used a case study in this qualitative research. The research participants of this study were the ninth grade of Islamic Junior High School in Tasikmalaya, consist of twenty five students. In collecting data, the researchers used triangulation method as data collection techniques. The instruments are observation, interview, and questionnaire. The result showed that most of students' perceptions are good. It is recommended for English teacher to used Reciprocal Teaching in Reading to promote students' critical thinking.
\end{abstract}

Key words: Reciprocal Teaching, Reading, Students' Critical Thinking

\section{INTRODUCTION}

One of the ways to get information is by reading, but nowadays students' current reading interest is very low. This can be seen from several schools in Tasikmalaya. Students spend more time for playing games and social media than reading text books or just visiting the library in their school. 
Many factors of students' low interest of reading. One of them is because the development of technology. The other factors that influence the students' low interest of reading are derived from the inside and outside of the students itself, such as nature, habits, self-expresion, does not supported by family and school environment.

In teaching and learning process a teacher must be able to understand each student's characteristic, especially for students who need more attention in teaching and learning process. Students are always passive and only listen to what is conveyed by the teacher when the teaching and learning process. They must be more concerned with the aim that these students can be more active and able to be invited forward.

Students who tend to be passive in the class do not mean they are stupid, but they only feel embarrassed and afraid of their friends. Students' self-mistrust sometimes come from their self. Low material mastery makes them afraid to express their opinions. All of that is the reason why they prefer to be passive when learning activities occurs.

Most students can not see the meaning of a text critically. The habit of reading culture fosters students' curiosity. In this activity, questions arise that must be solved by them self. Students are required to improve their thinking, which in turn will make students think critically. There are several previous studies that related to the implementation of reciprocal teaching in reading.

One of the previous studies was conducted by Okkinga et al. (2018). This research analyzed how reciprocal teaching could improve low-achieving adolescents' reading comprehension in whole-classroom settings. The next previous study was conducted by Yunus \& A'yun (2017), this research showed that there was a significant effect on reading comprehension to EFL. By using reciprocal teaching method, students could improve their reading comprehension to EFL students.

These previous studies strengthen this research. It can be seen from reciprocal teaching which has been proven to improve reading comprehension in students with low achievement. While in this research, the researcher does not only focus on students' reading comprehension, but also on how students think critically on reading lesson by using reciprocal teaching.

However, the present study focuses on how reciprocal teaching promotes students' critical thinking. More specifically, the researcher focuses in promoting students' critical thinking, that did not investigate in the previous studies. This study fills the gap by 
investaging on how the teacher promote students' critical thinking through reciprocal teaching. Thus, the researcher conducted a research entitled "Reciprocal teaching of Reading to Promote Students' Critical Thinking (A Case Study at the Ninth Grade of One Public Islamic Junior High School in Tasikmalaya)

\section{Reciprocal Teaching}

Reciprocal teaching is an instructional procedure designed to enhance students' comprehension of the text. There are four comprehension strategies: predicting, questioning, clarifying, and summarizing. Furthermore, reciprocal teaching is a teaching strategy where the learning process is more dominated by students itself. They are required to be more active, bold and creative in expressing their opinions.

According to Palinscar \& Brown (1984), reciprocal teaching is a strategy of collaborative reading that take on the students group in using the four strategies. They are predicting, questioning, clarifying, and summarizing. The teacher and several students meet in a group to read a piece of text, occasionally stopping to discuss and process the text aloud.

Students are taught cognitive strategies that help them construct meaning from texts and simultaneously monitor their reading comprehension. Additionally, the procedure of reciprocal teaching was designed by Anne Marrie Palincsar from Michigan state University and Anne Brown from the University of Illinois. Reciprocal teaching is characterized by: the first a dialog between students and teacher, each taking a turn in the role of dialogue leader. Second, reciprocal means, interaction were one person acts in response to the other. Third, structure dialogue using four strategies: questioning, summarizing, clarifying and predicting.

\section{Reading}

Reading is an activity that must be carried out by students to gain more knowledge besides the knowledge provide by teacher. According to Gilakjani \& Sabouri (2016) Reading is a significant activity that furthers the development of learners' various academic tasks. It helps readers decoding a text, analyzing, explaining, and expressing their own ideas about written materials (R Fahmi, L Youlia Friatin, L Irianti, 2020). In the classroom, reading is considered as the most important activity, not only as a source of information and pleasurable activity, but also as a means of extending one's knowledge of language. 
Reading is an activity that needs comprehension and interpretation of written language in which readers must be aware of an idea, understand it in terms of their experiential background and interpret it in relation to their own needs and purpose. As stated by Komariah et al. (2015), reading is one of the language skills that learners should master, however, reading proficiency is difficult to attain without having adequate skills and comprehension.

Reading is a complex process that involves components, processes, and factors with the aim of finding better ways of improving it among learners. According to Meniado (2016), reading is an interactive process of finding meanings from a text. It's series of cognitive activities that include a lot of dimensions like the understanding of words and their meanings, mindfulreaction, and integration.

Cohen (1998), states that for a reading process to be effective, it has to undergo three fundamental stages: the first stage is the pre-reading stage, the second one is the actual reading, and the last stage is the post reading stage. He goes on to assert that these main steps play a vital role in the reading process which is set to help readers practice various reading strategies.

In the pre- reading stage, readers may apply a number of strategies such as; guessing, scanning, predicting the genre of text they are going to read or identifying any difficulties apparent in the text. In doing so, the readers read the title of the text, relate the title to the readers' schemata, and then they predict the content of the text.

According to Perfetti \& Stafura, (2014), a general framework of reading systems must reflect reading more fully by adding word level processes to the higher level processes that are the focus of comprehension. This Reading Systems Framework makes the following claims about reading. Here are six essential skills needed for reading, and what might help struggling readers improve this skill.

The first is decoding. Decoding is a vital step in the reading process. Readers use this skill to sound out words they have heard before but have not seen written out. The ability to do that is the foundation for other reading skills. Decoding relies on an early language skill called phonemic awareness. Phonemic awareness enables readers to hear individual sounds in words (known as phonemes).

Second is fluency. To read fluently, readers need to instantly recognize words, including ones they can't sound out. Fluency speeds up the rate at which they can read and understand 
text. It's also important when readers encounter irregular words, like of and the, which can't be sounded out.

Third is vocabulary. To understand what you are reading, you need to understand most of the words in the text. Having a strong vocabulary is a key component of reading comprehension. Students can learn vocabulary through instruction, but they typically learn the meaning of words through everyday experience and also by reading.

Fourth is reasoning and background knowledge. Most readers relate what they have read to what they know. So it is important readers to have background or prior knowledge about the world when they read. They also need to be able to read between the lines and extract meaning even when it is not literally spelled out.

The fifth is working memory and attention. These two skills are both part of a group of abilities known as executive function. They're different but closely related. When the readers read, attention allows them to take in information from the text. Working memory allows them to hold on the information and use it to gain meaning and build knowledge from what they are reading. Working memory and attention are part of executive function.

Considering the explanation above, it is assumed that one of method that can be applied in teaching reading, it is reciprocal teaching method that can help students to become more understand in reading learning.

\section{Critical Thinking}

Critical thinking is needed by students in reading because student with critical thinking can understand the text deeply. According to Yousefi \& Mohammadi (2016), critical thinking is believed to have significant contributions to learners' academic context in the era of technology and explosion of information. Meanwhile, Kurland (2010), stated that critical thinking is a technique to reflect and evaluate what is read, so it helps students make a sound judgment and shape their beliefs. Critical thinking involves reflecting on the validity of what we have read in light of our prior knowledge and understanding of the world. In this regard, students need to encourage critical thinking skills and incorporate it into their academic studies.

According to Ekahitanond (2013), critical thinking skills in the higher-order thinking levels of Bloom's taxonomy (analysis, synthesis, evaluation) were significantly increased after 
they used the critical thinking model based on peer feedback strategy. Students were taught how to give reasons, comments, and feedback, through examples and practice.

Critical thinking skill is one of high-level thinking skill that becomes the indicator of learning goal accomplishment and skill that need to be attained by students. According to Thalib et al. (2017), the critical thinking skill empowerment that is done consistently in the learning process will make students competent in managing their learning process independently and increase their thinking skill.

Critical thinking is the ability to consider a range of information derived from many different sources, to process this information in a creative and logical manner, challenging it, analyzing it and arriving at considered conclusions which can be defended and justified.

Critical thinking to be purposeful, self-regulatory judgment which results in interpretation, analysis, evaluation, and inference, as well as explanation of the evidential, conceptual, or contextual considerations upon which that judgment. The ideal critical thinker is habitually inquisitive, well-informed, trustful of reason, open-minded, flexible, fair-minded in evaluation, honest in facing personal biases, diligent in seeking relevant information, reasonable in the selection of criteria, and persistent in seeking results which are as precise as the subject and the circumstances of inquiry permit (Abrami et al., 2015).

To reinforce students' critical thinking skills, teacher instruction should provoke students to presume, suspect, generalize, create, and assess, including giving chances for students to identify and solve problems, particularly those that are relevant and of interest and concern to students. According to Ekahitanond (2013), students' critical thinking skills can be mobilized after acquiring two important components of thinking. They are the ability to identify the parts of their thinking and evaluate the use of these parts.

Someone who thought critically doing their actions creatively can be trusted and have a quality reasons. According to Moon (2008, p.139), critical thinking is a comprehensive thought that involves criticism and creative thinking, which is primarily related to the quality of reasoning or argument that presented to support the beliefs or action taken.

Increasing critical thinking skill by using reciprocal teaching in reading learning can be seen from the results of several instruments that will be applied in this study. While in this study the researcher examined how reciprocal teaching promote students' critical thinking in 
reading lesson based on the steps that occurs in reciprocal teaching such as predicting process, questioning process, clarifying process, and summarizing process.

\section{METHOD}

The researchers used a case study in this qualitative research. In addition, this study focused on a single phenomenon which is one of the characteristics of a case study. The steps that the researchers took in this research is by taking the data from classroom observation, interview, and questionnaire. All of the data was taken to answer the research question in this research. It's to find out the implementation of reciprocal teaching in reading process to promote students' critical thinking, and to find out the students' perception after teaching by reciprocal teaching method.

The researchers took the participants purposively because the researcher wanted to fulfill what exactly need to answer the research question in this study. As mentioned by Creswell (2012, p.206), in purposive sampling, "researchers intentionally select individuals and sites to learn or understand the central phenomenon." In this regard, the participants in this study consist of 25 students.

\section{FINDINGS AND DISCUSSIONS}

After collecting the data from data observation, the interview, and the questionnaire the researchers conducted the analysis of each instrument that was described as follows:

\section{Teacher Promote Students' Critical Thinking by Reciprocal Teaching of Reading}

The classroom observation was conducted three times on $4^{\text {th }}$ until $6^{\text {th }}$ March 2019 . The classroom observation aimed to get deeper understanding of the teacher promote students' critical thinking by reciprocal teaching of reading. In fact, classroom observation was conducted to answer the first research question as follow: "How does the teacher promote students' critical thinking by reciprocal teaching of reading?". Then, the data were analyzed by coding, interpreted, and drawing the conclusion.

The step was implemented in this technique by the teacher it was divided into three sections. The first is opening section by greeting students, and checking students' attendance list. Second are main activity sections which consist of four strategies of reciprocal teaching, it 
is predicting, clarifying, questioning and summarizing. According to Palincsar \& Brown (1984), reciprocal teaching is an instructional procedure in which students learn to improve their reading comprehension through active participation in their reading process by using comprehension-fostering and comprehension-monitoring strategies. These strategies are predicting, clarifying, questioning, and summarizing. The last is helping students to use the strategies, managing the group discussion, checking students' comprehension of the text discussed, and closing section by reviewing the lesson.

In this observation, it was very important to observe students' critical thinking, while students' interaction, teacher action and activities when reciprocal teaching was implemented in the classroom. In learning process, the activities consist of three parts, they were opening, main activity and closing.

Based on the finding, it is concluded that in this learning process of reading by using reciprocal teaching method. Most of students were very active in expressing their opinions. It was seen from several students who answered question from other group members. They provide answers meaningfully and based on the different perspective. According to Yousefi \& Mohammadi (2016), critical thinking is a technique to reflect and evaluate what is read, so it helps students make a sound judgment and shape their beliefs. Critical thinking involves reflecting on the validity of what we have read in light of our prior knowledge and understanding of the world.

The researchers conducted interview to answer the first research question. It is to strengthen the data from classroom observation data. The student interviewed selected randomly by researcher. Students interviewed consist of three persons, and they took from each group. The interview itself consisted of five question, it is to find out how far students' critical thinking after learning by using reciprocal teaching.

Based on the findings fom the interview, it can be concluded that in this learning process of reading by using reciprocal teaching method. Most of students were very active in expressing their opinions. They provide answers meaningfully and based on the different perspective. Therefore, they were thinking critically. 


\section{Students' Perception Toward Reciprocal Teaching of Reading}

The step that the researcher interpreted the results of students' perception in learning reading by using reciprocal teaching is questionnaire. The questionnaire was given to participants to find out the data from the second research question. It is "What are students' perception toward reciprocal teaching?"

Questionnaire is the third instrument. This questionnaire analyze by computing the percentage data to answer the second research question. It is students' perception toward reciprocal teaching. From the data analysis of questionnaire, the researcher found that most of students feel interested when they were learning reading by reciprocal teaching method. It's can be seen from the table 4.4 that showed $96 \%$ answered 'yes' that learning reading by using reciprocal teaching method is interested. Furthermore, the researcher found that most of students feel that reciprocal teaching method increase their motivation and their courage when learning reading.

The questionnaire was given after teaching and learning process occur. The questionnaire was given to the ninth grades at one Islamic junior high schools in Tasikmalaya. The participants of the study were twenty five students. The data were analyzed to answer the research questions by describing the data and drawing the conclusion.

Meanwhile, based on the data analysis of questionnaire, the researchers found that most of students feel the positive effect when they were learning by reciprocal teaching method. As stated by Reichenberg \& Lofgren (2014), the benefits of reciprocal teaching that learners get are: A greater knowledge of the topic, improved reading skills, more positive attitudes when extracting, organizing and recording information, improved leadership, increased co-operation and greater initiative.

\section{CONCLUSIONS}

Reciprocal teaching can be used by the teacher as an alternative teaching technique in teaching reading also to promote students critical thinking. The students must always be motivated to learn English. They also must be brave and active in applying reciprocal teaching technique to comprehend a text. Never be shy in sharing the idea and learn as much as possible. 
The result of the research can be used as a reference for further researcher, and those who are interested in conducting the research with a similar topic. This research has weaknesses in the other fields, because it only aimed to investigate the reciprocal teaching method to promote students' critical thinking on reading. Other than that, for the next research, the researcher suggested to investigate the reciprocal teaching in speaking or writing lesson.

\section{REFERENCES}

Abrami, P. C., Bernard, R. M., Borokhovski, E., Wadington, D. I., \& Wadde, C. A. (2015). Strategies for Teaching Students to Think Critically: A Meta Analysis. Journal of Educational Research, 85 (2), 275-314.

Cohen, A. D. (1998). Strategies in Learning and Using a Second Language. Essex: Longman.

Creswell, J. W. (2012). Educational Research: planing, conducting, and evaluating quantitative and qualitative research.

Ekahitanond, V. (2013). Promoting university students ' critical thinking skills through peer feedback activity in an online discussion forum. Alberta Journal of Educational Research, 59 (2), 247-265.

Gilakjani, A. P., \& Sabouri, N. B. (2016). A Study of Factors Affecting EFL Learners' Reading Comprehension Skill and the Strategies for Improvement. International Journal of English Linguistics , 6 (5), 180-187.

Komariah, E., Ramadhona, P. A. R., \& Silviyanti, T. M. (2015). Improving Reading Comprehension through Reciprocal Teaching Method. Studies in English Language and Education , 2 (2), 87-102.

Kurland, D. J. (2010). How the language really works: The fundamentals of critical reading and effective writing, 4 (1), 70-76.

Meniado, J. C. (2016). Metacognitive Reading Strategies, Motivation, and Reading Comprehension Performance of Saudi EFL Students. English Language Teaching, 9(3), 117-129.

Moon, J. (2008). Critical Thinking: An Exploration of Theory and Practice. Canada: Routledge.

Okkinga, M., Steensel, R., Gelderen, A., \& Sleegers, P. (2018). Effects of Reciprocal Teaching on Reading Comprehension of Low-achieving Adolescents . The Importance of Specific Teacher Skills. Journal of Research in Reading , 41 (1), 20-41. 
Palincsar, A. S., \& Brown, A. L. (1984). Reciprocal Teaching of Comprehension Fostering and Comprehension- Monitoring Activities. Lawrence Erlbaum Associates , 2 (1), $117-$ 175.

Perfetti, C., \& Stafura, J. (2014). Word Knowledge in a Theory of Reading Comprehension. Scientific Studies ofReading , 1 (1), 22-37.

Reichenberg, M., \& Lofgren, K. (2014). An intervention study in Grade 3 based upon reciprocal teaching. Journal of Education and Learning, 8(2), 122-131.

R Fahmi, L Youlia Friatin, L Irianti. (2020). The Use of Flipped Classroom Model in Reading Comprehension. JALL (Journal Of Applied Linguistics And Literacy) 4 (1), 77-94

Thalib, M., Corebima, A. D., \& Ghofur, A. (2017). Comparison on Critical Thinking Skill and Cognitive Learning Academic Ability through Reading Questioning Answering. Jurnal Pendidikan Sains Volume, 5 (1), 26-31.

Yousefi, M., \& Mohammadi, M (2016). Critical Thinking and Reading Comprehension among Postgraduate Students : The Case of Gender and Language Proficiency Level. Journal of Language Teaching and Research , 7 (4), 802-807.

Yunus, M., \& A'yun, Q. (2017). The Efficacy of Reciprocal Teaching Method in Teaching Reading Comprehension to EFL Students. 2 (2), 134-146. 